\title{
Some data on grassflies (Diptera: Acalyptratae: Chloropidae) of Egypt
}

\author{
Материалы по змаковым мухам (Diptera: Acalyptratae: \\ Chloropidae) Египта
}

\author{
E.P. Nartshuk \\ Э.П. Нарчук
}

Zoological Institute of the Russian Academy of Sciences, Universitetskaya nab. 1, St. Petersburg 199034, Russia. E-mail: chlorops@zin.ru Зоологический институт Российской академии наук, Университетская наб. 1, Санкт-Петербург 199034, Россия.

KEY WORDS: Chloropidae, Diptera, new records, Egypt.

КЛЮЧЕВЫЕ СЛОВА: Chloropidae, Diptera, новые находки, Египет.

ABSTRACT. Eight species of Chloropidae recorded from Assouan, Egypt. Flies were collected on lawn in hotel garden. All species are considered as hemerodiaphores on Klausnitzer's classification. Lasiochaeta pubescens (Thalhammer, 1898) and Aphanotrigonum femorellum Collin, 1946 are recorded for Egypt for the first time.

РЕЗЮМЕ. Представлен список 8 видов Chloropidae, собранных на газоне в саду при отеле в Ассуане, Египет. Все виды рассматриваются как гемеродиафоры согласно классификации Клауснитцера. Lasiochaeta pubescens (Thalhammer, 1898) и Aphanotrigonum femorellum Collin, 1946 отмечаются как новые для Египта.

\section{Introduction}

There are two publications on Chloropidae from Egypt. Becker [1903] listed 18 species of 12 genera on material from several localities of the country. Collin [1949] had material mostly from Siwa Oasis (Lybian desert) and some other localities. He listed 13 species of 12 genera, seven of them were from Becker's list and six turned to be new to the Egyptian fauna. These 18 species are listed in the Catalogue of Palaearctic Diptera [Nartshuk, 1984]: Oscinellinae: Anacamptoneurum obliquum (Becker, 1903), Aphanotrigonum favillaceum (Becker, 1903), A. multicingulatum (Strobl, 1893), A. subfasciellum Collin, 1949, Anatrichus erinaceus Loew, 1860, Elachiptera flavofrontata Becker, 1903, E. lenis Collin, 1949, E. trisulcata Becker, 1903, Oscinella pusilla (Meigen, 1830), Rhopalopterum mimica (Collin, 1949), Scoliophthalmus trapezoids Becker, 1903, Siphunculina maculifrons Becker, 1903, Tricimba humeralis (Loew, 1858), T. setulosa Becker, 1903; Chloropinae: Assuania thalhammeri (Strobl, 1893), Chlorops lucidifrons (Becker, 1903), Cryptonevra rufipes (Collin, 1949), Eurina lurida (Meigen, 1830), E. triangularis Becker, 1903, Lagaroceras megalops Becker, 1903, Metopstigma tenuiseta (Loew, 1860), Platyceph- ala scapularum (Becker, 1907), Stenophthalmus ocellatus Becker, 1903, Thaumatomyia pallida (Collin, 1949). New small collection of Chloropidae from Egypt was taken by K.B. Gorodkov in Assouan (24.3052203 $\mathrm{N}$ $\left.32.532593^{\circ} \mathrm{E}\right)$. All specimens were collected $6^{\text {th }}$ of October 1974. Flies were taken on lawn in hotel garden.

\section{List of species}

\section{Subfamily Oscinellinae}

Aphanotrigonum femorellum Collin, 1946

$20^{\top} 0^{7}, 4$ 우요.

The species is distinguished from related species of the genus by short black spur on hid tibia.

Widely distributed species, known in Europe, Asia eastwards to Mongolia and North Africa in Tunisia. First record for Egypt.

Lasiochaeta pubescens (Thalhammer, 1898)

$30^{7} 0^{7}, 2$ 우.

The species is widely distributed, especially in southern part of the Palaearctic Region, was recorded in North Africa. First record for Egypt.

Oscinella pusilla (Meigen, 1830)

$31 \mathrm{O}^{7} \mathrm{O}^{7}, 34$ 우

Larvae develop in shoots of grasses. The species widely distributed in the Palaearctic Region.

Subfamily Chloropinae

Chlorops lucidifrons Becker, 1903

$20^{7} \sigma^{\top}, 4$ 우.

All specimens belong to variety, described by Becker [1903]: scutum with red stripes, only anterior part of the middle stripe and posterior part of the lateral stripes are black. Specimens mentioned by Collin [1949] have the same pattern of colour.

The species is known only from Egypt.

Lagaroceras megalops Becker, 1903

72 ○ $^{7}, 76$ 웅․

Species of this genus are known as haring larvae phytophagous developing in shoots of grasses. 
The species is known from Egypt, Ethiopia and Mozambique.

$$
\text { Metopostigma tenuiseta (Loew, 1860) }
$$
2 우요.

The species is widely spread in the Afrotropical Region and North Africa (Egypt), Sandi Arabia, Yemen and Israel.

Stenophthalmus ocellatus Becker, 1903

$1 \mathrm{O}^{\top}, 1$ ㅇ․

The species was reared from sugar cane and maize stem together with Sesamia sp. (Lepidoptera) and Anacamptoneurum obliquum Becker (Diptera: Chloropidae) [Deeming, AlDhafer, 2012]. Widely distributed species: Turkmenia, Yemen, Saudi Arabia, India, Egypt, Sudan, Nigeria.

\section{Discussion}

Examined collection consists of eight species of six genera, but a species named only to genera level.

The main bulk of specimens belongs to Lagaroceras magalops (148 specimens), next species - Oscinella pusilla (53 specimens). Both species have phytophagous larvae developing in shoots of grasses (Poaceae). Other species are presented by a few specimens. The collection presents of special interest as all specimens are collected in artificial lawn in garden near hotel. Examined species, especially two presented by numer- ous specimens, can be considered as hemerodiaphores according Klausnitzer's classification [1990]. Species belonging to the group are almost or entirely independent of anthropogenic changes of landscape. Two species Lasiochaeta pubescens (Thalhammer, 1989) and Aphanotrigonum femorellum Collin, 1946 are added to the Chloropidae fauna of Egypt.

ACKNOWLEDGEMENTS. The paper is made in frame of team No. 01201351183 and supported by RFFI No. 15-5453038.

\section{References}

Becker Th. 1903. Aegyptische Dipteren (Forsetzung und Schluss) // Mitteilungen aus dem zoologischen Museum in Berlin. Bd.2. H.3. S.67-195.

Collin J.E. 1949. Diptera: Empididae, Dolichopodidae, Aschiza and Acalyptratae. Results of the Armstrong college expedition to Siwa Oasis (Lybian desert), 1935 under the leadership of Prof. J. Omer-Cuper // Bulletin de la Societé Fouad 1 ${ }^{\text {er }} \mathrm{d}^{\text {'Entomologie. }}$ Cairo. Vol.33. P.175-225.

Deeming J.C., Al-Dhafer H.M. 2012. Chloropidae (Diptera: Cyclorrhapha) from the Arabian Peninsula // Zoology in the Middle East. Vol.58. P.3-82.

Klausnitzer B. 1990. [Ecology of urban fauna]. Moskwa: Mir. 249 pp. [in Russian, translation from German].

Nartshuk E.P. 1984. Family Chloropidae // Soós A., L. Papp (eds.). Catalogue of Palaearctic Diptera. Vol.10. Clusiidae - Chloropidae. Budapest: Akadémiai Kiadó. P.222-298. 